\begin{tabular}{lll}
\hline Volume : 1 & No : 2 November 2016 & ISSN : 2502 - 7069 \\
\hline
\end{tabular}

\title{
PERAN PROFESIONALISME GURU DALAM MENINGKATKAN KUALITAS PEMBELAJARAN SISWA DI SMAN 2 SELONG
}

Oleh :

\author{
Alfian Satriadi, Sudirman Wilian, Muhammad Zulfikar Syuaib \\ Magister Administrasi Pendidikan Program Pascasarjana Universitas Mataram \\ Alfiansatriadi_006@yahoo.com
}

\begin{abstract}
ABSTRAK:Penelitian ini difokuskan pada peran kompetensi profesional guru di SMAN 2 selong, dengan rumusan masalah, yaitu: 1) bagaimanakah bentuk pelaksanaan tugas profesional guru dalam mengembangkan profesinya untuk kualitas belajar siswa di SMAN 2 Selong, dan 2) bagaimanakah bentuk pelaksanaan tugas profesional guru yang mendukung pengembangan profesinya di SMAN 2 Selong. Penelitian ini menggunakan pendekatan kualitatif dengan metode deskriptif. Teknik pengumpulan data dilakukan dengan observasi, wawancara, dan studi dokumentasi. Subjek penelitian ini adalah guru yang sudah disertifikasi, sementara informan adalah kepala sekolah, guru, pegawai dan siswa di SMAN 2 Selong. Hasil penelitian ini menunjukkan bahwa: 1) bentuk pelaksanaan tugas profesional guru dalam mengembangkan profesinya adalah menjelaskan konsep materi dengan keterkaitan antara ilmu mata pelajaran, melakukan analisis SK-KD, melakukan pengembangan rencana pembelajaran, melakukan evaluasi (membuat jurnal pembelajaran), dan menggunakan pemebelajaran berbasis internet. 2) bentuk pelaksanaan tugas profesional guru dalam unsur pendukung pengembangan profesinya adalah melakukan workshop, ikut terlibat dalam kegiatan MGMP, melakukan kolaborasi dengan teman sejawat dan membuat time work.
\end{abstract}

Kata Kunci: Peran, Profesionalisme guru, Kompetensi profesional guru.

ABSTRACT: This study focused on the role of professional competence of teachers at SMAN 2 Selong, there are problems question of this research: 1) How the form of implementation of the teacher's professional duties in developing the quality of student learning in SMAN 2 Selong, and 2) How the form of implementation of the teacher's professional duties in supporting the development of teacher's profession in SMAN 2 Selong. This study used qualitative approach with descriptive methods. Data are collected by observation, interview and documentation study. The subject of this research is the teacher who has been certified, while the informant is the principal, teachers, staff and students at SMAN 2 Selong. The results of this study are: 1) the form of the implementation of the teacher's professional duties in developing teacher's profession, to explain the concept of relationship between subjects, analysis $S K-K D$, developing lesson plans, conduct evaluations (keep a learning journal), and using internet based learning. 
2) the form of implementation of teacher's professional duties in supporting development of the profession is doing a workshop, get involved in activities MGMP to collaborate with colleagues and make time work.

Keywords: Role, Professionalism of teachers, Professional competence of teachers.

\section{PENDAHULUAN}

Pendidikan merupakan usaha untuk meningkatkan kesejahteraan hidupan manusia yang merupakan bagian dari pembangunan nasional. Pendidikan diharapkan memberikan kontribusinya untuk mengembangkan generasi penerus bangsa menjadi warga negara berkualitas yang mampu menghadapai tantangan akademik dan bisnis di masa depan. Pendidikan yang bermutu merupakan syarat utama untuk mewujudkan kehidupan bangsa yang maju, modern dan sejahtera. Negara Indonesia harus mencetak orang-orang yang berjiwa mandiri dan mampu berkompetisi di tingkat dunia. Saat ini, Indonesia membutuhkan orang-orang yang dapat berfikir secara efektif, efisien dan produktif. Hal tersebut dapat diwujudkan jika kita mempunyai tenaga pendidik yang handal dan mampu mencetak generasi bangsa yang pintar dan bermoral.

Guru memegang peranan yang sangat penting dan strategis dalam upaya membentuk watak bangsa dan mengembangkan potensi siswa dalam kerangka pembangunan pendidikan di Indonesia. Kehadiran guru hingga saat ini tidak akan pernah dapat digantikan oleh yang lain, terlebih pada masyarakat Indonesia yang multi budaya sehingga kehadiran teknologi tidak dapat menggantikan tugas-tugas guru yang cukup kompleks dan unik. Menurut Undangundang Nomor 14 Tahun 2005 Pasal 1 Ayat 4, Profesi adalah pekerjaan atau kegiatan yang dilakukan oleh seseorang dan menjadi sumber penghasilan kehidupan yang memerlukan keahlian, kemahiran atau kecakapan yang memenuhi standar mutu atau norma tertentu serta memerlukan pendidikan profesi.

Sesuai dengan Undang-Undang Nomor 14 Tahun 2005 tentang guru dan dosen dalam PP. RI. Nomor 74 Tahun 2008 Pasal 1 Ayat 1 tentang guru disebutkan bahwa pendidik profesional mempunyai tugas utama mendidik, mengajar, membimbing, mengarahkan, melatih, dan mengevaluasi peserta didik pada pendidikan anak usia dini jalur pendidikan formal, pendidikan dasar dan pendidikan menengah. Pasal 3 Ayat 2 PP Nomor 74 Tahun 2008 menyatakan bahwa guru profesional yang demikian itu dipersyaratkan cukup kompeten dalam hal: kompetensi pedagogik, kompetensi kepribadian, kompetensi sosial dan kompetensi profesional. Guru merupakan komponen pendidikan yang sangat berperan penting dalam kegiatan pembelajaran. Kedudukan guru merupakan posisi yang penting dalam dunia pendidikan khususnya di lembaga pendidikan formal. Oleh karena itu, kebijakan sertifikasi bagi guru dan dosen memang suatu langkah yang strategis untuk dapat meningkatkan mutu pendidikan.

Profesionalisme harus dipandang sebagai proses yang terus menerus. Dalam proses ini, pendidikan prajabatan, pendidikan dalam jabatan termasuk penataran, pembinaan dari organisasi profesi tempat kerja, penghargaan masyarakat terhadap profesi keguruan, penegakan kode etik profesi, 
sertifikasi, peningkatan kualitas calon guru, dan imbalan secara bersama-sama menentukan pengembangan profesionalisme seseorang termasuk guru.

Sejumlah penelitian membuktikan bahwa guru yang profesional merupakan salah satu indikator penting dari sekolah berkualitas. Guru yang profesional akan sangat membantu proses pencapaian visi misi sekolah. Mengingat strategisnya peran yang dimiliki oleh seorang guru, usahausaha untuk mengenali dan mengembangkan profesionalisme guru menjadi sangat penting untuk dilakukan (Nurdin, 2005: 22). Oleh sebab itu, diperlukan guru yang memiliki kemampuan yang maksimal untuk mewujudkan tujuan pendidikan nasional dan diharapkan secara berkesinambungan mereka dapat meningkatkan kompetensinya, baik kompetensi pedagogik, kepribadian, sosial, maupun profesional. Dengan demikian, guru sebagai profesi selain memiliki peran dan tugas sebagai pendidik serta guru dituntut memberikan layanan profesional kepada peserta didik agar tujuan pembelajaran dapat tercapai.

Tugas dan peran guru sebagai pendidik profesional sesungguhnya sangat komplek, tidak terbatas pada saat interaksi proses belajar mengajar di dalam kelas tetapi juga pada saat di luar kelas. Menurut H Peterr (Afriyanti, 2013) bahwa tugas dan tanggung jawab guru yaitu: (1) Guru sebagai pengajar, (2) Guru sebagai pembimbing, (3) Guru sebagai administrator pendidikan. Profesionalisme tidak hanya karena faktor tuntutan dari perkembangan jaman, tetapi pada dasarnya juga merupakan suatu keharusan bagi setiap individu dalam kerangka perbaikan kualitas hidup manusia. Profesionalisme menuntut keseriusan dan kompetensi yang memadai, sehingga seseorang dianggap layak untuk melaksanakan sebuah tugas. Kita sadari bahwa profesionalisme guru merupakan sebuah kebutuhan yang tidak dapat ditunda-tunda lagi, seiring dengan semakin meningkatnya persaingan yang semakin ketat dalam era globalisasi seperti sekarang ini.

Dari hasil wawancara beberapa guru dan observasi awal yang dilakukan peneliti dapat disimpulkan beberapa permasalahan yang timbul dalam melaksanakan tugas di antaranya: 1) Beberapa guru tidak membuat rencana pelaksanaan pembelajaran (RPP), 2) Dalam pelaksanaan pembelajaran masih kurang, hal ini dapat dilihat dari guru yang belum dapat mengkondusifkan keadaan kelas menjadi tenang ketika ada siswa yang melakukan keributan di kelas, 3) Ada guru yang melaksanakan proses pembelajaran kurang sesuai dengan perencanaan pembelajaran yang telah dibuat, kebanyakan hanya sebagai bukti fisik saja, 4) Karya tulis berupa penulisan buku, artikel ilmiah, atau jurnal ilmiah yang dimuat di media sangat jarang dilakukan oleh guru, 5) Sebagian guru tetap mengikuti diklat peningkatan kompetensi, namun dalam hal penulisan karya tulis dan penelitian belum dilakukan secara optimal (wawancara dan observasi pada tanggal 21-22 Januari 2015 di SMAN 2 Selong).

Guru merupakan orang yang sangat berpengaruh dalam proses pembelajaran sehingga dapat meningkatkan kualitas belajar siswa. Faktor lain yang harus dilakukan dalam mencapai profesionalisme guru adalah, perlunya perubahan paradigma dalam proses pembelajaran. Anak didik tidak lagi ditempatkan sekedar sebagai obyek pembelajaran tetapi harus berperan dan diperankan sebagai subyek. Guru tidak lagi sebagai instruktur yang harus memposisikan dirinya lebih tinggi dari pada anak didik, 
tetapi lebih berperan sebagai fasilitator yang bersifat saling melengkapi. Dalam konteks ini, guru dituntut untuk mampu melaksanakan proses pembelajaran yang efektif, kreatif dan inovatif secara dinamis dalam suasana yang demokratis. Dengan demikian proses pembelajaran akan dilihat sebagai proses pembebasan dan pemberdayaan, sehingga tidak terpaku pada aspek-aspek yang bersifat formal.

Beberapa hasil penelitian yang relevan dengan penelitian yang ingin dilakukan oleh peneliti tentang profesionalisme guru adalah sebagai berikut:

Hasil penelitian yang dilakukan oleh Afriyanti (2013) tentang pelaksanaan tugas guru profesional di SMA Negeri Kota Pariaman. menunjukkan bahwa guru sudah menjalankan tugasnya dengan baik yang ditinjau dari pelaksanaan tugas pokok mengajar meliputi: perencanaan pelaksanaan pembelajaran, evaluasi hasil pembelajaran, dan tindak lanjut hasil pembelajaran sudah tinggi dengan skor rata-rata yang diperoleh sebesar 4,3. Pelaksanaan tugas guru profesional di SMA Negeri Kota Pariaman ditinjau dari pengembangan profesi meliputi: pengembangan diri, publikasi ilmiah, karya inovatif sudah tinggi dengan skor ratarata yang diperoleh sebesar 4,19. Selain itu, Pelaksanaan tugas guru profesional ditinjau dari kegiatan pendukung meliputi: pengalaman organisasi, tugas tambahan sudah tinggi. Hal ini dapat dilihat dari skor rata-rata yang diperoleh sebesar 4,1.

Sedangkan hasil penelitian yang dilakukan oleh Muna dan Sutjiroso (2012) tentang pengaruh profesionalisme guru dan karakteristik siswa terhadap prestasi belajar siswa disebutkan bahwa terdapat pengaruh positif dan signifikan antara profesionalisme guru mata pelajaran produktif terhadap prestasi belajar siswa jurusan teknik bangunan SMK Negeri 2 Yogyakarta sebesar 7,1\%.

Selanjutnya, penelitian yang membahas tentang pengaruh pengembangan profesionalisme guru SMP terhadap peningkatan mutu pendidikan di Kabupaten Aceh Timur dilakukan oleh Bustami (2009) bahwa: Pengambangan profesionalisme guru mempengaruhi peningkatan mutu pendidikan sebesar $32 \%$, selebihnya $68 \%$ dipengaruhi oleh faktor-faktor lain. Oleh karena itu, salah satu komponen besar dari penelitian tersebut adalah profesionalisme guru yang memiliki tugas dalam melaksanakan proses pembelajaran dengan baik sekaligus sebagai pribadi, keluarga dan masyarakat maka guru memiliki harapan yang tinggi terhadap kualitas pembelajaran siswa yang berdampak pada mutu pendidikan.

Penelitian lain yang dilakukan oleh Supriadi (2009) tentang pengembangan profesionalisme guru sekolah dasar dikemukakan bahwa pengembangan kemampuan guru disesuaikan dengan tingkat dan jenjang pendidikan yang pada hakekatnya pengembangan kemampuan professional guru ditekankan pada tiga kemampuan dasar, yaitu: kemampuan profesi, kemampuan pribadi dan kemampuan sosial.

Profesionalisme guru merupakan kondisi, arah, nilai, tujuan, dan kualitas suatu keahlian dan kewenangan dalam bidang pendidikan atau pembelajaran yang berkaitan dengan pekerjaan seseorang yang menjadi mata pencaharian. Sementara itu, guru yang profesional adalah guru yang memiliki kompetensi yang dipersyaratkan untuk melakukan tugas pendidikan dan pembelajaran. Sebagaimana dijelaskan oleh Rusman (2014: 19) guru profesional adalah 
orang yang memiliki kemampuan dan keahlian khusus dalam bidang keguruan, sehingga mampu melakukan tugas dan fungsi sebagai guru dengan kemampuan yang maksimal. Menurut Aqib dan Rohmanto (2007: 146) kualitas profesionalisme ditunjukkan oleh lima unjuk kerja sebagai berikut: 1) keinginan untuk selalu menampilkan prilaku yang mendekati standar ideal, 2) meningkatkan dan memelihara citra profesi, 3) keinginan untuk senantiasa mengejar kesempatan penegmbangan profesional yang dapat meningkatkan dan memperbaiki kualitas pengetahuan dan keterampilan, 4) mengejar kualitas dan cita-cita dalam profesi, dan 5) memiliki kebanggaan terhadap profesinya.

Kompetensi profesional merupakan salah satu kemampuna dasar yang harus dimiliki seorang guru. Adapun beberapa pandangan para ahli mengenai kompetensi profesional yaitu: Menurut Cooper (Alma. et al, 2014: 138) bahwa ada empat (4) kompetensi profesional yaiutu: a). mempunyai pengetahuan tentang dan tingkah laku manusia, b). mempunyai pengetahuan dan menguasai bidang studi yang dibinanya, c). mempunyai sikap yang tepat tentang diri sendiri, sekolah, teman sejawat, dan bidang studi yang dibinanya, dan d). mempunyai keterampilan dalam teknik mengajar. Menurut Johnson (Alma. et al, 2014: 138-139) mencakup: a). penguasaan materi pengajaran yang terdiri atas penguasaan bahan yang harus diajarkan dan konsep-konsep dasar keilmuan yang diajarkan dari bahan yang diajarkannya, b). penguasaan dan penghayatan atas landasan, wawasan kependidikan dan keguruan, dan c). penguasaan proses-proses kependidikan, keguruan dan pembelajaran siswa.

Pandangan Rusdiana dan Heryati (2015: 100)kompetensiprofesional merupakan kemampuan guru sedikitnya mencakup: 1) validitas atau tingkat ketepatan materi, 2) keberartian atau tingkat kepentingan materi, 3) relevansi dengan tingkat kemampuan peserta didik, 4) kemenarikan, menarik perhatian/ memotivasi peserta didik, dan 5) kepuasan, merupakan hasil pembelajaran peserta didik benar-benar bermanfaat bagi kehidupannya.

Rusman (2014: 57-58) menjelaskan kompetensi profesionalyaitu kemampuanyang harus dimiliki guru berkenaan dengan aspek menyampaikan pembelajaran, melaksanakan proses pembelajaran, dan melakukan evaluasi. Guru mempunyai tugas untuk mengajarkan kegiatan belajar sisiwa untuk mencapai tujuan pembelajaran, untuk itu guru dituntut mampu menyampaikan bahan pelajaran. Guru harus selalu memperbaharui dan menguasai materi pelajaran yang disajikan. Adapun kriteria kompetensi profesional guru sebagai berikut: a) Menguasai materi, struktur, konsep, dan pola pikir keilmuan yang mendukung mata pelajaran yang diampu, b) Menguasai standar kompetensi dan kompetensi dasar mata pelajaran/bidang pengembangan yang diampu, c) Mengembangkan mata pejalaran yang diampu secara kreatif, d) Mengembangkan keprofesionalan secara berkelanjut dengan melakukan tindakan reflektif, dan e) Memanfaatkan teknologi informasi dan komunikasi (TIK) untuk berkomunikasi dan mengembangkan diri.

Senada dengan pendapat Rusdiana dan Heryati (2015: 101) bahwa pengembangan materi pembelajaran harus diarahkan untuk mencapai tujuan dan membentuk kompetensi peserta didik berdasarkan SK-KD dan indikator kompetensi, guru melakukan pengembangan materi standar untuk membentuk kompetensi peserta didik. Ramayulis (2013: 87) bahwa dengan teknologi informasi pendidik dapat 
memberikan layanan tanpa harus berhadapan langsung dengan pesesrta didik, demikian sebaliknya peserta didik tidak hanya menerima informasi dari pendidik saja tetapi juga dapat memperoleh informasi dalam lingkup yang luas dan berbagai sumber melalui cyber space atau ruang maya dengan menggunakan komputer atau internet. Sebagaimana Volme dan Mills (Sagala, 2012: 195) mengemukakan bahwa pada dasarnya profesi adalah sebagai suatu spesialisasi dari jabatan intelektual yang diperoleh melalui studi dan training, bertujuan memberikan keterampilan melalui pelayanan dan bimbingan pada orang lain untuk mendapatkan bayaran atau gaji. Sedangkan guru adalah pendidik profesional yang memiliki tugas utama untuk mendidik, mengajar, membimbing, mengarahkan, melatih, menilai dan mengevaluasi (Aqib dan Elham, 2007: 149).

Pengembangan profesi adalah kegiatan guru dalam rangka pengamalan ilmu dan pengetahuan, teknologi, dan keterampilan untuk meningkatkan mutu, baik bagi proses belajar mengajar dan profesionalisme tenaga kependidikan lainnya maupun dalam rangka menghasilkan sesuatu yang bermanfaat bagi pendidikan dan kebudayaan (Aqib dan Elham, 2007: 155). Jabatan guru merupakan jabatan profesional, oleh karena itu pemegangnya harus selalu meningkatkan pengetahuan, sikap dan keterampilan secara terus menerus. Sebagai jabatan yang harus dapat menjawab tantangan perkembangan masyarakat, jabatan guru harus selalu dikembangkan, dimutakhirkan dan selalu mengadakan pembaharuan sesuai dengan tuntutan tugasnya. Seperti yang dijelaskan beberapa kegiatan guru yang termasuk kegiatan pengembangan profesi yaitu a) Mengadakan penelitian di bidang pendidikan, b) Menemukan teknologi tepat guna di bidang pendidikan, c) Membuat alat pelajaran, peraga atau bimbingan, d) Menciptakan karya tulis, e) Mengikuti kegiatan pengembangan kurikulum (Aqib dan Elham,2007: 155).

Berdasarkan uraian di atas, dipandang perlu untuk dilakukan studi lebih lanjut tentang peran profesionalisme guru yang dilihat dari aspek pengembanngan dan unsur pendukung profesionalismenya. Hal ini penting untuk dilakukan, mengingat faktor profesionalisme merupakan salah satu faktor yang sangat berpengaruh terhadap kualitas pembelajaran siswa. oleh karena itu, permasalahan utama yang dikaji dalam penelitian ini adalah tentang peran profesionalisme guru dalam meningkatkan kualitas pembelajaran siswa di SMAN 2 Selong.

\section{METODE PENELITIAN}

Penelitian ini menggunakan pendekatan penelitian kualitatif, yaitu suatu pendekatan penelitian yang berusaha untuk mengungkapkan masalah secara apa adanya (alamiah) dari kondisi sebenarnya pada situasi tertentu. Moleong (2013: 6) menyatakan bahwa penelitian kualitatif adalah penelitian yang bermaksud untuk memahami fenomena secara holistik dan dengan cara deskripsi dalam bentuk katakata dan bahasa, pada suatu konteks khusus yang alamiah dengan memanfaatkan berbagai metode. Jenis penelitian ini merupakan penelitian diskriptitf kualitatif, yang bersifat "Case Study". Subjek penelitian adalah guruguru yang sudah disertifikasi yang berjumlah 10 orang. Sementara informan penelitian adalah kepala SMAN 2 Selong, guru yang belum di sertifikasi, pegawai atau staf, dan siswa. Metode pengumpulan data dalam penelitian ini meliputi observasi, wawancara 
dan dokumentasi. Adapun teknik untuk mengumpulakan data yaitu menggunakan purposive sampling, kemudian teknik lain yang digunakan untuk mendapatkan informan adalah snowball sampling. Analisis data dilakukan dengan cara: a) reduksi data; b) display data; dan c) verifikasi (milles \& Hubberman, 2009: 16-20)

\section{HASIL DAN PEMBAHASAN}

Berdasarkan kajian teori yang telah diuraikan sebelumnya, peran profesionalisme guru dalam meningkatkan kualitas belajar siswa ada dua yaitu peran pengembangan profesi dan unsur pendukung profesinya. Adapun pembahasan dua sub fokus tersebut dapat dipaparkan sebagai berikut:

\section{a. Peran Profesional Guru dalam Mengembangkan Profesinya Untuk Meningkatkan Kualitas Pembelajaran Siswa}

Indikator peran profesional guru dalam mengembangkan profesinya untuk meningkatkan kualitas belajar siswa khususnya pada kompetensi profesional guru meliputi lima aspek yaitu: 1) menguasai materi, struktur, konsep, dan pola pikir keilmuan yang mendukung mata pelajaran yang diajarkan, 2) menguasai stantar kompetensi dan kompetensi dasar mata pelajaran yang diampu, 3) mengembangkan materi pembelajaran yang diampu secara kreatif, 4) mengembangkan keprofesionalan secara berkelanjutan dengan melakukan tindakan reflektif, dan 5) memanfaatkan teknologi informasi dan komunikasi untuk mengembangkan diri.

Hasil penelitian pada indikator pertama menunjukkan bahwa peran guru dalam aspek penguasaan materi, struktur, konsep, dan pola pikir keilmuan yang mendukung mata pelajaran yang diajarkan adalah menjelaskan konsep materi yang disampaikan dengan mengaitkan antar mata pelajaran dengan keberagaman siswa (secara kontekstual), memantau kinerja siswa, dan memberikan pelayanan yang baik terhadap siswa, sebagaimana terungkap dari data hasil penelitian berikut ini:

“...peran kita sebagai guru adalah memantau tingkat pemahaman siswa dalam menerima materi dan konsep yang kita ajarkan, menjelaskan fungsi dan tujuan mata pelajaran, tidak lepas juga kita memotivasi serta memantau kinerja siswa..."

Terkait dengan hal ini, hasil penelitian menunjukkan bahwa hal penting yang harus dimiliki guru adalah kemampuan menjabarkan materi dalam kurikulum. Oleh karena itu, temuan dalam penelitian ini mendukung pandangan guru tentang penentuan secara tepat materi yang relevan dengan kebutuhan dan kemampuan peserta didik, keterkaitan antara materi yang diajarkan dengan tujuan atau kompetensi yang akan dicapai. Selain itu, guru memfasilitasi peserta didik dalam menerima materi serta membentuk kompetensi dirinya.

Hasil penelitian ini mempertegas pandangan Rusdiana dan Heryati (2015: 100) tentang kemampuan guru dalam menjabarkan materi dalam kurikulum mencakup lima hal pokok yaitu: 1) validitas atau tingkat ketepatan materi, 2) keberartian atau tingkat kepentingan materi, 3) relevansi dengan tingkat kemampuan peserta didik, 4) kemenarikan, menarik perhatian/memotivasi peserta didik, dan 5) kepuasan, merupakan hasil pembelajaran peserta didik benar-benar bermanfaat bagi kehidupannya.

Selain itu, temuan ini juga memperkuat 
salah satu pandangan Johnson (Alma. et al, 2014: 138-139) yang menyatakan kompetensi profesional mencakup: a) penguasaan materi pengajaran yang terdiri atas penguasaan bahan yang harus diajarkan dan konsep-konsep dasar keilmuan yang diajarkan dari bahan yang diajarkannya, b) penguasaan dan penghayatan atas landasan, wawasan kependidikan dan keguruan, dan c) penguasaan proses-proses kependidikan, keguruan dan pembelajaran siswa.

Hasil penelitian tentang aspek peran guru dalam menguasai standar kompetensi dan kompetensi dasar mata pelajaran yang diampu yaitu: melakukan analisis SK-KD (indikator), membuat RPP dalam beberapa pertemuan berdasarkan SK-KD sesuai dengan kebutuhan siswa. Temuan tersebut menunjukkan bahwa dalam setiap materi pembelajaran khususnya pada standar kompetensi dan kompetensi dasar (SK-KD) setiap kelompok mata pelajaran perlu dianalisis dan dibatasi. Sebagaimana terungkap dari data hasil penelitian berikut:

“....setelah kita melihat dan memahami SK-KD-nya (indikator), kita sebagai guru membuat RPP sesuai dengan materi dan kebutuhan siswa."

Hasil penelitian di atas memperkuat pendapat yang dikemukakan oleh Suprihatiningrum (2013: 117) bahwa guru yang mempunyai kompetensi profesional harus mampu memilah dan memilih serta mengelompokkan materi pembelajaran yang akan disampaikannya kepada siswa sesuai dengan jenisnya. Oleh karena itu, tanpa kompetensi tersebut dapat dipastikan bahwa guru akan menghadapi berbagai kesulitan dalam membentuk kompetensi siswa, bahkan dapat dikatakan gagal dalam melaksanakan pembelajaran.

Sebagaimana juga terungkap dari hasil penelitian yang menunjukkan bahwa pendapat guru (informan) terhadap peran guru dalam menguasai standar kompetensi dan kompetensi dasar (SK-KD) mata pelajaran yang diampu yaitu bahwa guru mampu merencanakan dan melaksanakan pembelajaran dengan baik. Sebagaimana terungkap dari data hasil penelitian berikut:

“...dalam pembuatan RPP disesuaikan dengan materi, kemudian menentukan metode dan jenis penilaian yang kita gunakan, tetapi kita sebagai guru memahami SK-KD dan indikator yang ada di silabus."

Hasil penelitian ini menunjukkan bahwa SK-KD beserta indikator-indikatornya, tujuan pembelajaran, materi, dan penilaian serta waktu untuk merealisasikannya harus ditetapkan sesuai dengan kepentingan pembelajaran, sehingga peserta didik memperoleh kesempatan dan pengalaman belajar yang optimal. Hasil penelitian tersebut sesuai dengan pendapat Rusdiana dan Heryati (2015: 101) yang mengatakan bahwa pengembangan materi pembelajaran harus diarahkan untuk mencapai tujuan dan membentuk kompetensi peserta didik berdasarkan SK-KD dan indikator kompetensi. Guru melakukan pengembangan materi standar untuk membentuk kompetensi peserta didik.

Hasil penelitian ini juga menunjukkan bahwa melaksanakan atau mengelola pembelajaran merupakan tahap program yang telah dibuat oleh guru. Terkait dengan hal ini, hasil observasi dan dokumentasi yang dilakukan menunjukkan bahwa dalam 
satu KD ada empat penilaian sikap dan ada empat keterampilan. Penggunaan masingmasing penilaian diambil dari beberapa pertemuan yaitu: pertemuan pertama, kedua, ketiga, dan keempat. Pertemuan pertama yang dinilai adalah keterampilan dalam melakukan praktikum, kemudian keterampilan membuat produk yang dituangkan dalam bentuk laporan. Bukti fisik dari komponen ini berupa RPP yang sudah disahkan oleh guru dan kepala sekolah.

Apa yang telah dilakukan oleh guru-guru sudah sesuai dengan apa yang dinyatakan oleh Rusman (2014: 5) bahwa rencana pelaksanaan pembelajaran (RPP) disusun untuk setiap kompetensi dasar yang dapat dilaksanakan dalam satu kali pertemuan atau lebih. Hal yang sama juga dikemukakan oleh Suprihatiningrum (2013: 224) bahwa perencanan pembelajaran merupakan persiapan mengelola pembelajaran yang akan dilaksanakan dalam kelas pada setiap tatap muka. Tanpa perencanaan yang matang, mustahil target pembelajaran dapat tercapai secara maksimal. Pada sisi lain, melalui RPP dapat diketahui kadar kemampuan guru dalam menjalankan profesinya.

Hasil penelitian salanjutnya mengenai aspek peran guru dalam mengembangkan materi pembelajaran yang diampu secara kreatif adalah memantau tingkat pemahaman siswa, memahami kurikulum, membuat perangkat pembelajaran sesuai karakteristik siswa, serta menggunakan strategi dan metode pembelajaran yang bervariasi. Pengembangan materi diperlukan dalam rangka menyelaraskan antara materi yang ada dengan perubahan dan perkembangan, baik yang terkait dengan pola pikir siswa maupun keterbatasan materi itu sendiri.

Dalam setiap pengembangan materi pembelajaran, guru seharusnya memperhatikan apakah materi yang akan diajarkan sesuai dengan tujuan dan kompetensi yang akan dibentuk. Selain itu, informasi yang diberikan kepada siswa secara lisan maupun tertulis yang dimengerti oleh siswa diharapkan dapat mengembangkan daya pikir dan nalarnya secara maksimal baik dengan berpikir induktif ataupun deduktif. Sebagaimana terungkap dari data hasil penelitian berikut:

“...para guru disini menggunakan pendekatan sincetific, tetapi guru yang akan mengembangkan sendiri materi yang diampu, materi yang akan disampaikan disesuaikan dengan karakteristik siswa atau kondisi sekolah. Terutama supaya siswa tidak jenuh, biasanya guru memberikan siswa menemukan sendiri, melakukan sediri sesuai dengan LKS problem solving yang guru berikan...”

Hasil penelitian di atas memperkuat pendapat Rusdiana dan Heryati (2014:102) yang mengemukakan bahwa ada tiga (3) tipe materi pembelajaran yang menyangkut peranan guru dalam pengembangan dan penyampaian pembelajaran, yaitu: a) mendesain dan mengembangkan materi pembelajaran individual, serta tugas guru adalah memotivator dan membimbing kemajuan peserta didik dalam menyelesaikan materi dan membentuk kompetensi, b) guru memilih materi pembelajaran yang sudah dengan strategi pembelajaran dalam pembentukan kompetensi, c) pembelajaran sangat bergantung pada guru untuk menyampaikan semua materi pembelajaran menurut strategi yang telah dikembangkan.

Hasil penelitian selanjutnya tentang peran guru dalam aspek mengembangkan keprofesionalan secara berkelanjutan dapat dilihat dari upaya guru dalam melakukan tindakan reflektif yaitu melakukan evaluasi, 
membuat jurnal pembelajaran, dan membuat portofolio. Sebagaimana terungkap dari data hasil wawancara berikut:

“...kita sebagai guru melakukan refleksi dengan cara menulis di portofolio, kadang membuat jurnal kegiatan pembelajaran, selain itu kita sebagai guru di evaluasi oleh teman sejawat.

Pernyataan ini menunjukkan bahwa peran guru dalam mengembangan keprofesionalan dapat dikatakan belum maksimal, hanya sebatas melakukan evaluasi dalam bentuk membuat jurnal dan melakukan penilaian portofolio belum sampai pada tahap melakukan penelitian ilmiah seperti melakukan penelitian tindakan kelas (PTK) dengan membuat karya tulis ilmiah (KTI). Hal ini juga ditegaskan oleh Suprihatiningrum (2013: 203) bahwa penelitian dilakukan untuk mengetahui lebih dalam tentang prilaku siswa, gaya belajar, dan segala sesuatu yang berkaitan dengan proses pembelajaran. Oleh karena itu, seorang guru dituntut menjadi lebih baik dengan melakukan penelitian dan membuat karya ilmiah.

Selanjutnya hasil penelitian mengenai peran guru dalam memanfaatkan teknologi informasi dan komunikasi untuk mengembangkan diri yaitu menggunakan dan mempersiapkan materi pembelajaran dalam sistem jaringan komputer, mengakses jaringan internet untuk memperkaya sumber/bahan belajar, dan memperbanyak media atau metode pembelajaran. Sebagaimana terungkap dari data hasil wawancara berikut:

“...guru dan siswa di sekolah memanfaatkan jaringan internet yang ada untuk mengunduh sumber-sumber belajar, mencari video model pembelajaran di kelas dan untuk mencari artikel-artikel."

Pernyataan ini menunjukkan bahwa guru dituntut untuk memiliki kompetensi dalam pemanfaatan teknologi pembelajaran terutama internet, agar mampu memanfaatkan berbagai pengetahuan teknologi dan informasi dalam melaksanakan tugasnya. Hal ini sejalan dengan pendapat Ramayulis (2013: 87) bahwa dengan teknologi informasi, pendidik dapat memberikan layanan tanpa harus berhadapan langsung dengan pesesrta didik. Demikian sebaliknya, peserta didik tidak hanya menerima informasi dari pendidik saja tetapi juga dapat memperoleh informasi dalam lingkup yang luas dari berbagai sumber melalui cyber space atau ruang maya dengan menggunakan komputer atau internet.

\section{b. Pelaksanaan Tugas Profesional Guru dalam Unsur Pendukung Pengembangan Profesinya di SMAN 2 Selong.}

Sebagaimana diuraikan pada deskripsi hasil penelitian bahwa pelaksanaan tugas profesional guru dalam unsur pendukung pengembangan profesinya adalah melakukan workshop, melakukan diskusi, mengikuti kegiatan MGMP/KKG, melakukan kolaborasi dengan teman sejawat dan guru bidang studi lainnya. Pengembangan profesi melibatkan strategi-strategi yang dapat membantu individu/organisasi untuk lebih efektif dalam pelaksanaan pencapaian individu/organisasi, misi, tujuan, dan hasilnya. Sebagaimana kutipan data hasil wawancara berikut:

“...kita melakukan workshop di sekolah, melakukan diskusi mengenai kesulitan- 
kesulitan di kelas, ikut dalam kegiatan MGMP atau KKG dan melakukan kerjasama dengan semua staf atau pegawai..."

Pernyataan di atas senada dengan yang dikemukakan oleh Suprihatiningrum (2013: 172) bahwa pengembangan profesi adalah suatu proses untuk membantu organisasi atau individu dalam melakukan pekerjaan secara efektif. Selain itu, hasil studi dokumentasi yang dilakukan peneliti menemukan bahwa kualifikasi akademik guru sebagai unsur pendukung pengembangan profesinya yaitu memiliki tingkat pendidikan dari S1 sampai S2. Artinya guru memiliki kemauan untuk melakukan studi lanjut yang dapat meningkatkan kualitas profesionalnya. Sebagaimana dipertergas oleh pendapat Lardizabal (Suprihatiningrum 2013: 172) bahwa pendidikan lanjutan bagi guru hendaknya diarahkan paling tidak pada tiga hal, yaitu peningkatan pengetahuan materi subjek, peningkatan pengetahuan pendidikan spesifik bidang studi, dan pendidikan profesional.

Selain itu, pengalaman guru menjadi pengurus organisasi kependidikan, organisasi sosial, dan/atau mendapat tugas tambahan dapat mempengaruhi pengembangan profesinya. Salah satu kegiatan yang dilakukan oleh guru di SMAN 2 Selong adalah melakukan MGMP. Dengan adanya MGMP atau pertemuan ilmiah diharapkan mampu meningkatkan profesionalisme guru dalam melaksanakan tugasnya sebagai seorang pendidik. Sebagaimana kutipan dari hasil wawancara sebagai berikut:

“...bentuk kerjasama guru-guru disini adalah melakukan diskusi, MGMP, serta mengikuti pelatihan pengembangan kurikulum..."
Hasil penelitain di atas senada dengan pendapat Collette \& Chiappetta (Suprihatiningrum 2013: 174) bahwa pengembangan profesional guru dapat ditempuh melalui beberapa cara yaitu inservice training, memberdayakan musyawarah guru mata pelajaran (MGMP), memberdayakan organisasi profesi dan mengevaluasi kinerja guru. Oleh karena itu, dalam upaya meningkatan profesional guru melalui kegiatan tersebut diharapkan menjadi sebuah wadah yang dapat meningkatkan kualitas guru yang pada akhirnya berdampak pada kualitas belajar siswa.

\section{SIMPULAN}

1. Peran profesionalisme guru dalam mengembangkan profesinya di SMAN 2 Selong.

Dilihat dari pemahaman tentang peran profesionalisme guru dalam mengembangkan profesinya dapat disimpulkan beberapa poin penting yaitu: pertama, guru melakukan pengembangan bahan ajar atau materi yang relevan dengan kebutuhan dan kemampuan siswa. Kedua, dalam menyusun prosedur pembelajaran guru dapat melakukannya dengan tepat dan cermat sehingga memudahkan siswa menerima materi untuk membentuk kompetensi dirinya. Ketiga, dalam melakukan perencanaan pembelajaran guru sudah mampu melakukan analisis terhadap standar kompetensi (SK) dan kompetensi dasar (KD) setiap kelompok mata pelajaran yang akan disamapaikan ke siswa. Keempat, dalam mengembangkan keprofesionalannya guru tampak belum secara maksimal dalam melakukan tindakan reflektifkarena guru hanya membuat jurnal pembelajaran dan pengisian portofolio tetapi seharusnya guru melakukan penelitian ilmiah. Kelima, dalam pelaksanaan 
pembelajaran guru tidak hanya memanfaatkan pertemuan di kelas tetapi juga menggunakan jaringan internet dalam menyelesaikan materi pembelajaran. Artinya guru dan siswa dapat memberikan atau menyelesaikan tugas-tugas sekolah melalui komunikasi jaringan internet.

2. Pelaksanaan tugas profesional guru dalam unsur pendukung pengembangan profesinya di SMAN 2 Selong.

Dilihat dari pemahaman tentang peran profesionalisme guru khususnya pada unsur pendukung pengembangan profesinya dapat disimpulkan beberapa poin penting yaitu: pertama, guru melakukan workshop, diskusi, mengikuti kegiatan MGMP atau KKG, melakukan kolaborasi dengan teman sejawat dan guru bidang studi lainnya. Kedua, sebagian guru melakukan studi lanjut ke jenjang S2 guna mendukung pengembangan profesionalismenya sehingga dapat meningkatkan kualitas pembelajaran siswa. Ketiga, guru-guru di SMAN 2 Selong sudah dapat melaksanakan tugas profesionalismenya dengan baik. Hal ini terlihat dari peran yang dimiliki oleh guru yaitu: memiliki rasa pengabdian yang tinggi, tanggungjawab sosial yang memandang profesi guru sebagai komponen penting di masyarakat khususnya masyarakat sekolah serta pentingnya organisasi profesi guru dalam pengembangan layanan profesionalnya.

\section{SARAN}

1. Semua guru yang ada di SMAN 2 Selong perlu meningkatkan profesionalisme secara terus menerus dan sadar akan peran beserta tugas yang dimiliki.

2. Semua guru harus mengikuti tuntutan perkembangan profesi secara global dan tututan masyarakat yang menghendaki pelayanan yang lebih baik.

3. Guru perlu memperkuat diri melalui keikutsertaan dalam forum ilmiah, seperti: mengikuti pertemuan asosiasi profesi, ikut terlibat dalam penelitian ilmiah atau pembuatan karya ilmiah, mengikuti workshop, mengikuti pelatihan profesionalisme guru baik di tingkat kabupaten/kota, provinsi, nasional ataupun ke tingkat internasional, .

4. Kepada peneliti lain, dapat melakukan kajian lebih lanjut mengenai profesionalisme guru dengan melihat dari beberapa aspek kompetensi yang lain, seperti aspek kompetensi pedagogik, kompetensi sosial dan kompetensi kepribadian.

\section{DAFTAR PUSTAKA}

Afriyanti, $P$.

2013. "Pelaksanaan Tugas Guru Profesional di Sekolah Menengah Atas Negeri Kota Pariaman.” Jurnal Ilmiah Administrasi Pendidikan. 1, (1), 377461.

Agung, I.

2014. Mengembangkan Profesionalitas Guru. Jakarta: Bee Media Pustaka.

Alma, B. et al.

2014. Guru Profesional. Bandung: Alfabeta.

Arikunto, S.

2006. Prosedur Penelitian Suatu

Pendekatan Praktik. Jakarta: Rineka Cipta.

Aqib, Z., dan Elham, R.

2007. Membangaun Profesionalisme Guru dan Pengawas Sekolah. Bandung: Yrama Widya. 
Bafadal, I.

2003. Manajemen Peningkatan Mutu

Sekolah Dasar Dari Sentralisasi Menuju

Desentralisasi. Jakarta: Bumi Aksara.

Bustami.

2009. "Pengaruh Pengembangan

Profesionalisme Guru SMP Terhadap

Peningkatan Mutu Pendidikan di

Kabupaten Aceh Timur.” Jurnal Ilmiah

Administrasi Pendidikan.

Geoge, R.

2004. Filsafat Pendidikan (Isu-isu

Kontemporer \& Solusi Alternatif).

Yogyakarta: Idea Pers.

Hadi, S.

1999. Metodologi Research. Yogyakarta:

Yayasan Penerbitan Fakultas Psikologi

UGM. Vol. 2.

Hamidi.

2010. Metode Penelitian Kualitatif (Pendekatan Praktis Penulisan Proposal dan Laporan Penelitian). Malang: UMM Press.

Herdiansyah, H. 2013. Wawancara,

Observasi, dan Focus Groups Sebagai Instrumen Penggalian Data Kualitatif. Jakarta: Rajawali Pers.

Jufri, W.

2013. Belajar dan Pembelajaran Sains.

Bandung: Pustaka Reka Cipta.

Muna, C. dan Bambang, S.

2012. "Pengaruh Profesionalisme

Guru Mata Pelajaran Produktif Dan

Karakteristik Siswa Terhadap Prestasi

Belajar Siswa Jurusan Teknik Bangunan

SMK Negeri 2 Yogyakarta”. Jurnal Pendidikan. Yogyakarta.

Muslich, M.

2007. Sertifikasi Guru Menuju

Profesionalisme Pendidik. Malang:

Bumi Aksara.
Miles dan Huberman,

2009. Analisis Data kualitatif. Jakarta:

Penerbit Universitas Indonesia.

Moleong, L.

2013. Metodologi Penelitian Kualitatif.

Bandung: Remaja Rosdakarya.

Nurdin, S.

2005. Profesionalismedan Impelementasi

Kurikulum Guru. Jakarta: Quantum

Teaching.

Ramayulis.

2013. Profesi dan Etika Keguruan.

Jakarta: Kalam Mulia.

Riduwan.

2007. Metode dan Teknik Menyusun

Tesis. Bandung: Alfabeta.

Riyanto, Y.

2007. Metodologi Penelitian Pendidikan

Kualitatif dan Kuantitatif. Surabaya: Unesa University Press.

Rusdiana, A dan Heryati, Y.

2015. Pendidikan Profesi Keguruan

(Menjadi Guru Inspiratif dan Inovatif).

Bandung: Pustaka Setia.

Rusman.

2014. Model-Model Pembelajara

(Mengembangkan Profesionalisme

Guru). Jakarta: Raja Grafindo Persada.

Sagala, S.

2012. Administrasi Pendidikan

Kontemporer. Bandung: Alfabeta.

Satori, D., dan Komariah, A.

2013. Metodologi Penelitian Kualitatif.

Bandung: Alfabeta.

Soekanto, S., dan Sulistyowati, B.

2014. Sosiologi Suatu Pengantar. Jakarta:

Raja Grafindo Persada.

Sugiyono.

2012. Metode Penelitian Kombinasi

(Mixed Methods). Bandung: Alfabeta.

Supriadi, O. 
Alfian Satriadi, Sudirman Wilian, Muhammad Zulfikar Syuaib

2009. "Pengembangan profesionalisme guru sekolah dasar". Jurnal Tabularasa PPs Unimed. 6, (1), 27-38.

Suprihatiningrum, J.

2013. Guru Profesional Pedoman

Kinerja Kualifikasi \& Kompetensi Guru. Yogyakarta: AR-RUZZ Media.

Undang-Undang No. 14 Tahun

2005. Undang-Undang Republik

Indonesia Nomor: 24 Tahun 2005

Tentang Guru dan dosen. 